\title{
Evaluation of the Nutrient Composition of Maize in Different NPK Fertilizer Levels Based on Multivariate Method Analysis
}

\author{
Csaba Bojtor $\mathbb{D}^{\mathbb{D}},{ }^{1}$ Árpád Illés, ${ }^{1}$ Seyed Mohammad Nasir Mousavi $\mathbb{D}^{1},{ }^{1}$ Adrienn Széles $\mathbb{D}{ }^{1}{ }^{1}$ \\ Brigitta Tóth $\mathbb{D}^{2},{ }^{2}$ János Nagy $\mathbb{D}^{1},{ }^{1}$ and Csaba L. Marton $\mathbb{D D}^{1,3}$ \\ ${ }^{1}$ Institute of Land Utilisation, Technology and Regional Development, \\ Faculty of Agricultural and Food Sciences and Environmental Management, University of Debrecen, H-4032 Debrecen, \\ 138 Böszörményi St, Hungary \\ ${ }^{2}$ Institute of Food Science, Faculty of Agricultural and Food Sciences and Environmental Management, University of Debrecen, \\ H-4032 Debrecen, 138 Böszörményi St, Hungary \\ ${ }^{3}$ Eötvös Loránd Research Network, Centre for Agricultural Research, Agricultural Institute, H-2462 Martonvásár, \\ 2 Brunszvik St, Hungary
}

Correspondence should be addressed to Csaba Bojtor; bojtor.csaba@agr.unideb.hu

Received 2 March 2021; Revised 19 March 2021; Accepted 22 March 2021; Published 2 April 2021

Academic Editor: Vera Popovic

Copyright (C) 2021 Csaba Bojtor et al. This is an open access article distributed under the Creative Commons Attribution License, which permits unrestricted use, distribution, and reproduction in any medium, provided the original work is properly cited.

\begin{abstract}
One of the critical issues in using micronutrient fertilisers is the comparison of methods and amounts of fertiliser use, which is very important from the aspect of increasing production and economic viewpoint. The aim of this research was to analyse the nutrient composition of different parts of the maize (Zea mays L. FAO 490) during the growing season with six-level nitrogen fertilisation supplies at five phenological stages. The study included essential nutrients as nitrogen $(\mathrm{N})$, phosphorus $(\mathrm{P})$, potassium $(\mathrm{K})$, and sulphur $(\mathrm{S})$ (in first cluster) and calcium $(\mathrm{Ca})$ and magnesium $(\mathrm{Mg}$ ) (in second cluster) in treatments on different leaf stage. Growth stages have different nutrient demands based on their actual demand. The first cluster included nitrogen and sulphur and the second included calcium and zinc in the NPK treatments on the stalk of plants. Nitrogen and potassium had their maximum effect on the stalk of maize during the growing season. Magnesium and copper were the second most important and desirable factors during the different growth stages and treatments in relation to the stalk. Nitrogen and calcium had their maximum impact during the yield formation stage and nitrogen and phosphorus had their most desirable effect during the grain filling stage. The effect of nitrogen on the quantitative and qualitative properties of maize showed that nitrogen increases the production of dry matter, grain yield, and its components. The maximum amount of absorption in the plants occurs before the accumulation of applied fertiliser, which is the prelude to the production of maximum biomass.
\end{abstract}

\section{Introduction}

Maize (Zea mays L.) is one of the most important crops as both human food and livestock feed. Its primary cultivation goal is to maximize productivity and yield while maintaining crop quality [1]. The biology of nutrient uptake and distribution in maize shows no change compared to previous years. Higher yields and biomass production of the hybrids with the latest genetic stock can be associated with increased plant nutrient uptake and higher utilisation of soil nutrient content [2]. Optimal nitrogen supply has a significant role in the growth characteristics of plants, as it is the main factor for plant cell components, primarily due to its role played in the photosynthetic apparatus [3]. The nitrogen use efficiency (NUE) of maize is estimated at $33 \%$ globally, which is negatively affected by fertiliser leaching under the root zone and denitrification [4]. According to Surendran et al. [5], maize absorbs about $10-20 \%$ of its total nitrogen requirements up to the V4 stage, whereas during 6 weeks of growth from V4 to VT, N accumulation approaches $60-70 \%$ of total $\mathrm{N}$ uptake. 
TABLE 1: NPK fertilisation doses applied in the long-term multifactorial experiment.

\begin{tabular}{|c|c|c|c|c|}
\hline Fertilisation level & $\mathrm{N}\left(\mathrm{kg} \mathrm{ha}^{-1}\right)$ & $\mathrm{P}_{2} \mathrm{O}_{5}\left(\mathrm{~kg} \mathrm{ha}^{-1}\right)$ & $\mathrm{K}_{2} \mathrm{O}\left(\mathrm{kg} \mathrm{ha}^{-1}\right)$ & Total $\left(\mathrm{kg} \mathrm{ha}^{-1}\right)$ \\
\hline No & 0 & 0 & 0 & 0 \\
\hline N1 & 60 & 184 & 216 & 460 \\
\hline N2 & 120 & 184 & 216 & 520 \\
\hline N3 & 180 & 184 & 216 & 580 \\
\hline N4 & 240 & 184 & 216 & 640 \\
\hline N5 & 300 & 184 & 216 & 700 \\
\hline
\end{tabular}

In agronomy research, two different methods have been used to assess the adequate nutrient supply of maize. The first one is the analysis of the whole plant in the early vegetative stage (V4-V6) after the depletion of the seed's nutrient reserves [6]. The second one is the ear-leaf analysis at the tasseling stage (VT). The early whole plant sampling method allows for supplemental nutrient replenishment if the analysis shows nutrient deficiencies [7]. In the VT period, the ear-leaf sampling is too late to determine an additional nutrient application for nutrient corrections of the plants [8]. Nutrient concentrations can be redetermined during the ripening stage and those values provide reliable information on the uptake of each nutrient and on the nutrient balance among the different plant organs and between the soil-plant systems [9].

Nitrogen supply plays an important role in plant senescence and can greatly affect the remobilisation of different nutrients from vegetative to generative organs [10]. The remobilisation and transport of many micronutrients (such as $\mathrm{Fe}, \mathrm{Mn}, \mathrm{Cu}$, and $\mathrm{Zn}$ ) depend mainly on different organic acids and nicotianamine-based chelates [11, 12]. The $\mathrm{N}$ excess or deficiency can be a modifying factor of this process affecting the regulation of the synthesis of these nitrogenous chelates [13]. An optimized, balanced nutrition system with focus on every essential nutrient must be implemented to maximize maize productivity and yield quality. A better understanding of nutrient balances may be achieved by exploring physiological characteristics (macroand micronutrient uptake and partitioning in different crop growth stages among the different plant organs) [14].

The aim of this research was to analyse the essential nutrient composition of different parts of the maize plant during the growing season with 6-level nitrogen fertilisation supply. Determination of the nitrogen fertilisation effect on the nutritional status and partitioning of modern maize hybrids analysed with different multivariate statistical methods can provide a basis for the farmers to implement hybrid and site-specific nutrient management systems with the goal of reducing the environmental impact of overfertilisation.

\section{Materials and Methods}

The experiment was performed at the Látókép Experiment Site at the University of Debrecen, Hungary $\left(47^{\circ} 33^{\prime} \mathrm{N}, 21^{\circ}\right.$ $26^{\prime} \mathrm{E}, 111 \mathrm{~m}$ asl). A mid-ripening maize hybrid (Zea mays L. FAO 490) with favourable phenometric characteristics was used in this experiment. The effects of different nitrogen supplies as a variable rate abiotic stress and the interrelationship among the essential nutrients were examined through the nutrient composition and partitioning of the different plant organs.

The soil type of experimental field area is calcareous chernozem, the liquid limit (LL) is $43-45$, humus content ( $\mathrm{Hu} \%)$ is $2.7-2.8$, and the thickness of the humus layer is around $80 \mathrm{~cm} \mathrm{[15].} \mathrm{The} \mathrm{investigated} \mathrm{plots} \mathrm{are} \mathrm{part} \mathrm{of} \mathrm{a} \mathrm{35-}$ year long-term multifactorial nitrogen fertilisation experiment in a maize monoculture field, which allows studying and evaluating the long-term effects of different nitrogen supply doses (Table 1).

The sowing date was 20/04/2019, using $7.6 \mathrm{~m}^{2}$ experimental plot size with a density of 73,000 plant ha ${ }^{-1}$. During the growing season, five different phenological stages were used to analyse the nutrient composition of the vegetative and generative plant organs, two-leaf stage (V2), four-leaf stage (V4), eight-leaf stage (V8), tasseling stage (VT), and physiological maturity (R6). Four representative plants were collected at each sampling time in each of the six different $\mathrm{N}$ levels, in all 120 whole plants during the growing season. All plant samples were separated into leaf, stalk, and at the R6 stage cob and grain, dried at $60^{\circ} \mathrm{C}$ to a constant weight, weighed to obtain the dry matter of the plants (DM), and ground into fine powder. The complex mineral profile of the different plant organs obtained at the five sampling stages (leaves, stalk, grain, and cob, respectively) was determined in an accredited laboratory using microwave-assisted multielement analysis [16].

Sample preparation for the laboratory analysis was as follows: two parallel measurements were made from each sample. $0.4 \mathrm{~g}$ sample was weighed, and then $2 \mathrm{ml}$ of high purity water and $4 \mathrm{ml}$ of cc. nitric acid were added to the samples. The adequate digestion program was chosen according to the Milestone Ultrawave microwave system manual (Milestone Inc., USA). Sample extraction with microwave digestion was performed at $200^{\circ} \mathrm{C}$, with a holding time of 10 minutes. ICP-OES analysis was used for the determination of phosphorus, potassium, magnesium, calcium, sulphur, iron, and manganese concentration. Sample of $5 \mathrm{ml}$ was pipetted into a plastic test tube, and $5 \mathrm{ml}$ of deionized water, $0.2 \mathrm{ml}$ of the acid mixture, and $0.2 \mathrm{ml}$ of 100 ppm Y-containing ISTD (internal standard) were added to the sample. The mixture was homogenized, and then it was put into the 5900 ICP-OES (Agilent Technologies Inc., USA). The zinc, copper, molybdenum, and nickel concentration of the samples were determined from the homogenized mixture with 7900 ICP-MS (Agilent Technologies Inc., USA). Extracted sample of $5 \mathrm{ml}, 1 \mathrm{ml}$ of the acid mixture, and $4 \mathrm{ml}$ of deionized water were added to the test 


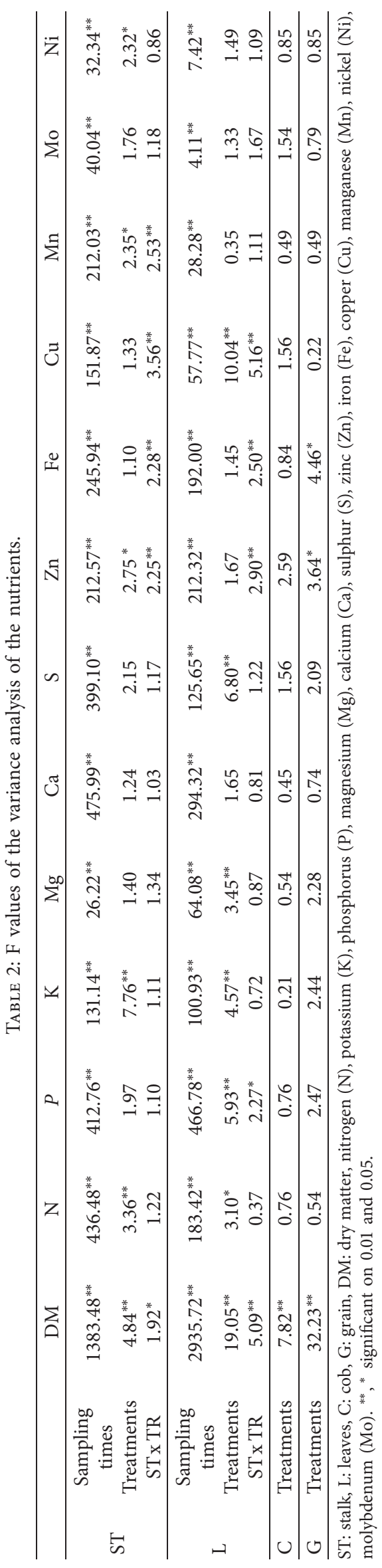


TABLE 3: Correlation analysis between nutrients.

\begin{tabular}{|c|c|c|c|c|c|c|c|c|c|c|c|c|}
\hline & & $\mathrm{N}$ & $P$ & $\mathrm{~K}$ & $\mathrm{Mg}$ & $\mathrm{Ca}$ & $S$ & $\mathrm{Zn}$ & $\mathrm{Fe}$ & $\mathrm{Cu}$ & $\mathrm{Mn}$ & Mo \\
\hline \multirow{11}{*}{ Stalk } & $\mathrm{P}$ & $0.852^{* *}$ & & & & & & & & & & \\
\hline & $\mathrm{K}$ & $0.563^{*}$ & $0.600^{* *}$ & & & & & & & & & \\
\hline & $\mathrm{Mg}$ & $0.721^{* *}$ & $0.782^{* *}$ & 0.498 & & & & & & & & \\
\hline & $\mathrm{Ca}$ & $0.784^{* *}$ & $0.826^{* *}$ & 0.220 & $0.659^{* *}$ & & & & & & & \\
\hline & $S$ & $0.942^{* *}$ & $0.871^{* *}$ & $0.566^{*}$ & $0.739^{* *}$ & $0.808^{* *}$ & & & & & & \\
\hline & $\mathrm{Zn}$ & $0.719^{* *}$ & $0.878^{* *}$ & 0.333 & $0.786^{* *}$ & $0.842^{* *}$ & $0.752^{* *}$ & & & & & \\
\hline & $\mathrm{Fe}$ & $0.835^{* *}$ & $0.802^{* *}$ & 0.269 & $0.684^{* *}$ & $0.870^{* *}$ & $0.821^{* *}$ & $0.793^{* *}$ & & & & \\
\hline & $\mathrm{Cu}$ & $0.608^{* *}$ & 0.439 & 0.082 & 0.293 & $0.681^{* *}$ & $0.617^{* *}$ & 0.418 & $0.639^{* *}$ & & & \\
\hline & $\mathrm{Mn}$ & $0.859^{* *}$ & $0.820^{* *}$ & $0.519^{*}$ & $0.747^{* *}$ & $0.723^{* *}$ & $0.883^{* *}$ & $0.742^{* *}$ & $0.720^{* *}$ & $0.526^{*}$ & & \\
\hline & Mo & $0.628^{* *}$ & 0.426 & 0.345 & 0.462 & 0.352 & $0.593^{*}$ & 0.331 & 0.449 & 0.362 & $0.598^{*}$ & \\
\hline & $\mathrm{Ni}$ & $0.664^{* *}$ & 0.473 & 0.371 & 0.451 & 0.401 & $0.642^{* *}$ & 0.325 & 0.492 & 0.387 & $0.567^{*}$ & $0.852^{* *}$ \\
\hline \multirow{11}{*}{ Leaves } & $\mathrm{P}$ & $0.794^{* *}$ & & & & & & & & & & \\
\hline & K & $0.787^{* *}$ & $0.713^{* *}$ & & & & & & & & & \\
\hline & $\mathrm{Mg}$ & 0.485 & $0.516^{*}$ & 0.266 & & & & & & & & \\
\hline & $\mathrm{Ca}$ & 0.192 & 0.361 & 0.005 & $0.748^{* *}$ & & & & & & & \\
\hline & S & $0.808^{* *}$ & $0.834^{* *}$ & $0.808^{* *}$ & 0.343 & 0.180 & & & & & & \\
\hline & $\mathrm{Zn}$ & $0.670^{* *}$ & $0.878^{* *}$ & $0.563^{*}$ & $0.687^{\text {** }}$ & $0.573^{*}$ & $0.639^{* *}$ & & & & & \\
\hline & $\mathrm{Fe}$ & $0.806^{* *}$ & $0.829^{* *}$ & $0.639^{* *}$ & $0.629^{* *}$ & 0.453 & $0.729^{* *}$ & $0.803^{* *}$ & & & & \\
\hline & $\mathrm{Cu}$ & -0.196 & -0.243 & -0.283 & 0.119 & 0.413 & -0.136 & -0.170 & -0.133 & & & \\
\hline & $\mathrm{Mn}$ & $0.636^{* *}$ & $0.554^{*}$ & $0.600^{*}$ & 0.196 & -0.038 & $0.584^{*}$ & 0.390 & $0.554^{*}$ & -0.112 & & \\
\hline & Mo & 0.120 & 0.081 & 0.150 & -0.109 & -0.184 & 0.055 & 0.049 & 0.108 & -0.200 & 0.202 & \\
\hline & $\mathrm{Ni}$ & 0.171 & 0.095 & 0.184 & -0.027 & -0.183 & 0.113 & 0.094 & 0.160 & -0.214 & 0.127 & $0.609^{* *}$ \\
\hline \multirow{11}{*}{ Cob } & $\mathrm{P}$ & 0.093 & & & & & & & & & & \\
\hline & $\mathrm{K}$ & 0.076 & 0.230 & & & & & & & & & \\
\hline & $\mathrm{Mg}$ & 0.180 & $0.759^{* *}$ & 0.002 & & & & & & & & \\
\hline & $\mathrm{Ca}$ & -0.025 & $0.617^{* *}$ & 0.476 & $0.603^{* *}$ & & & & & & & \\
\hline & $S$ & 0.368 & $0.771^{* *}$ & 0.431 & $0.668^{* *}$ & $0.587^{*}$ & & & & & & \\
\hline & $\mathrm{Zn}$ & -0.334 & 0.366 & 0.248 & 0.273 & $0.533^{*}$ & 0.012 & & & & & \\
\hline & $\mathrm{Fe}$ & 0.027 & 0.361 & -0.005 & 0.276 & 0.173 & 0.427 & 0.025 & & & & \\
\hline & $\mathrm{Cu}$ & 0.323 & 0.476 & -0.009 & 0.362 & 0.256 & $0.711^{* *}$ & -0.370 & 0.308 & & & \\
\hline & $\mathrm{Mn}$ & -0.102 & -0.022 & 0.061 & 0.076 & 0.087 & 0.162 & -0.185 & 0.420 & 0.045 & & \\
\hline & Mo & 0.006 & $0.606^{* *}$ & 0.075 & 0.439 & 0.273 & $0.571^{*}$ & 0.093 & $0.605^{* *}$ & 0.420 & 0.118 & \\
\hline & $\mathrm{Ni}$ & -0.031 & 0.322 & -0.030 & 0.189 & 0.120 & 0.341 & 0.053 & $0.989^{* *}$ & 0.253 & 0.394 & $0.616^{* *}$ \\
\hline \multirow{11}{*}{ Grain } & $\mathrm{P}$ & 0.130 & & & & & & & & & & \\
\hline & $\mathrm{K}$ & -0.006 & $0.908^{* *}$ & & & & & & & & & \\
\hline & $\mathrm{Mg}$ & 0.139 & $0.974^{* *}$ & $0.834^{* *}$ & & & & & & & & \\
\hline & $\mathrm{Ca}$ & -0.045 & 0.007 & -0.030 & -0.015 & & & & & & & \\
\hline & $S$ & 0.015 & 0.370 & 0.191 & 0.428 & 0.066 & & & & & & \\
\hline & $\mathrm{Zn}$ & -0.154 & $0.570^{*}$ & $0.677^{* *}$ & $0.525^{*}$ & 0.055 & 0.265 & & & & & \\
\hline & $\mathrm{Fe}$ & 0.225 & $0.509^{*}$ & 0.379 & $0.556^{*}$ & -0.017 & 0.448 & -0.058 & & & & \\
\hline & $\mathrm{Cu}$ & -0.289 & -0.007 & 0.149 & -0.010 & 0.111 & -0.174 & 0.055 & 0.313 & & & \\
\hline & $\mathrm{Mn}$ & 0.069 & 0.318 & 0.337 & 0.314 & -0.161 & 0.232 & 0.103 & 0.220 & -0.108 & & \\
\hline & Mo & -0.193 & -0.294 & -0.354 & -0.326 & 0.298 & 0.014 & -0.298 & -0.020 & 0.143 & -0.185 & \\
\hline & $\mathrm{Ni}$ & -0.157 & 0.100 & 0.122 & 0.054 & -0.255 & -0.247 & 0.245 & -0.073 & 0.112 & 0.106 & 0.070 \\
\hline
\end{tabular}

Nitrogen $(\mathrm{N})$, potassium $(\mathrm{K})$, phosphorus $(\mathrm{P})$, magnesium $(\mathrm{Mg})$, calcium $(\mathrm{Ca})$, sulphur $(\mathrm{S})$, zinc $(\mathrm{Zn})$, iron $(\mathrm{Fe})$, copper $(\mathrm{Cu})$, manganese $(\mathrm{Mn})$, nickel $(\mathrm{Ni})$, molybdenum (Mo). ${ }^{* *},{ }^{*}$ significant on 0.01 and 0.05 .

tube for the analysis. A sample of each matrix type was prepared twice. Blank samples were prepared in each series of measurements by measuring water of the same quantity instead of a sample. Due to possible inhomogeneity, two parallel digests were made from each sample and the final result was calculated from the average of these.

Nitrogen concentration was measured using the Dumas combustion method [17]. Samples were subjected to oxidative digestion at a high temperature $\left(900^{\circ} \mathrm{C}\right)$ with a controlled oxygen supply. The resulting flue gases passed through a copper oxide-platinum catalyst using a $\mathrm{CO}_{2}$ carrier gas, thus ensuring complete oxidation. After the subsequent reduction processes and the purification of the carrier gas, the nitrogen content remaining in the $\mathrm{CO}_{2}$ carrier gas was detected in a thermal conductivity detector (VELP NDA 702, Velp Scientific, Italy). The $\mathrm{N}_{2}$ volume provided an electrical measurement signal, from which the nitrogen content of the various burned samples was measured and calculated based on a preprepared calibration curve.

2.1. Statistical Analysis. The experimental design is twofactor strip-plot type with four replicates, providing the 

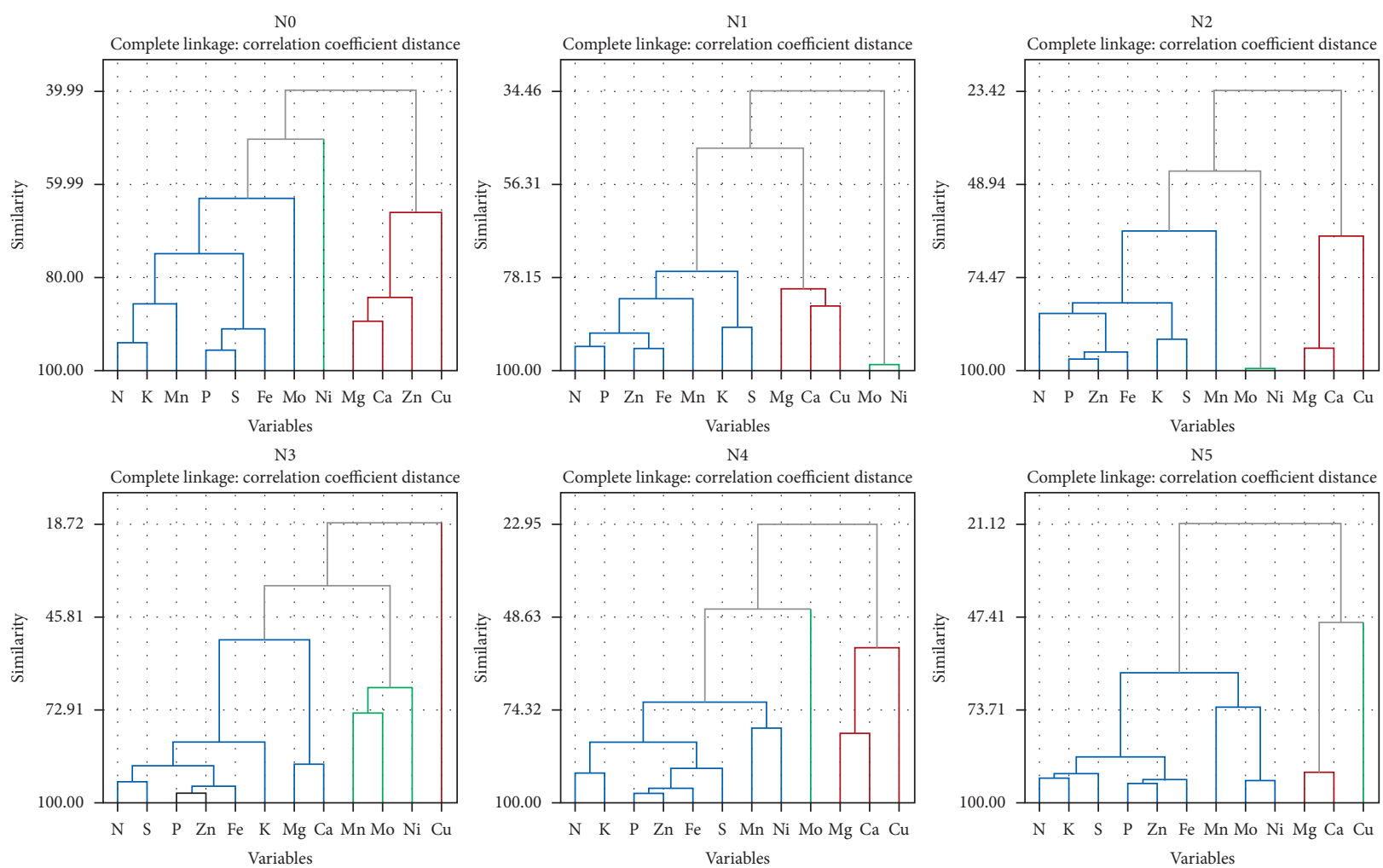

FIGURE 1: Cluster of NPK in nutrients with means of sampling times on leaves. Nitrogen $(\mathrm{N})$, potassium (K), phosphorus (P), magnesium $(\mathrm{Mg})$, calcium $(\mathrm{Ca})$, sulphur $(\mathrm{S})$, zinc $(\mathrm{Zn})$, iron $(\mathrm{Fe})$, copper $(\mathrm{Cu})$, manganese $(\mathrm{Mn})$, nickel $(\mathrm{Ni})$, and molybdenum $(\mathrm{Mo})$.

adequate layout for the statistical evaluation of the results. Analysis of variance, correlation, cluster, and AMMI analysis were used in the statistical analysis. The clustering purpose is to divide the observations into similar groups so that each cluster's data have the most similarity and the observations of different clusters have the least similarity. The summable component of the AMMI model was used, without considering the interaction, to justify the variance of experiments. This model is called AMMI, and if the multiplicative component of AMMI also takes into account the interaction, it is called model $\mathrm{F}$, depending on which component is used.

\section{Results}

The analysis of variance showed that the sampling time effect was significant on all nutrients at the level of one percent on stalk and leaves. The treatment effect was significant on dry matter, nitrogen, potassium, zinc, manganese, and nickel. The interaction between sampling times in treatments was significant on dry matter, zinc, iron, copper, manganese, molybdenum, and nickel in the stalk. The treatment effect was significant on dry matter, nitrogen, phosphorus, potassium, magnesium, sulphur, and copper on the leaves section. Sampling times and treatment interactions were significant on dry matter, phosphorus, zinc, iron, and copper on the leaves section. Variance analysis indicated that the treatment effect was significant on the dry matter in the cob and dry matter of grain, zinc, and iron in the grain (Table 2).
3.1. Correlation Analysis. Correlation analysis showed that nitrogen has a significantly positive correlation with phosphorus, potassium, magnesium, calcium, sulphur, zinc, iron, copper, manganese, and molybdenum. Phosphorus had a significant positive correlation with potassium, magnesium, calcium, sulphur, zinc, iron, copper, manganese, and molybdenum. Potassium had a significant positive correlation with sulphur and manganese. Magnesium had a significant positive correlation with calcium, sulphur, zinc, iron, and manganese. Calcium had a significant positive correlation with sulphur, zinc, iron, copper, and manganese. Sulphur had a significant and positive correlation with zinc, iron, copper, manganese, molybdenum, and nickel. Among the micronutrients, zinc had a significant positive correlation with iron and manganese, iron had a significant positive correlation with copper and manganese, copper with manganese, manganese with molybdenum, and molybdenum with nickel in the stalk part. Nitrogen had a significant positive correlation with phosphorus, potassium, sulphur, zinc, iron, and manganese, phosphorus had a significant positive correlation with potassium, magnesium, sulphur, zinc, iron, and manganese, potassium with sulphur, zinc, iron, and manganese, magnesium with calcium, zinc, and iron, sulphur with zinc and manganese, calcium with zinc, zinc with iron, iron with manganese, and nickel with molybdenum on leaves. Phosphorus had a significant positive correlation with magnesium, calcium, sulphur, and molybdenum, magnesium with calcium and sulphur, calcium with sulphur and zinc, sulphur with copper and 

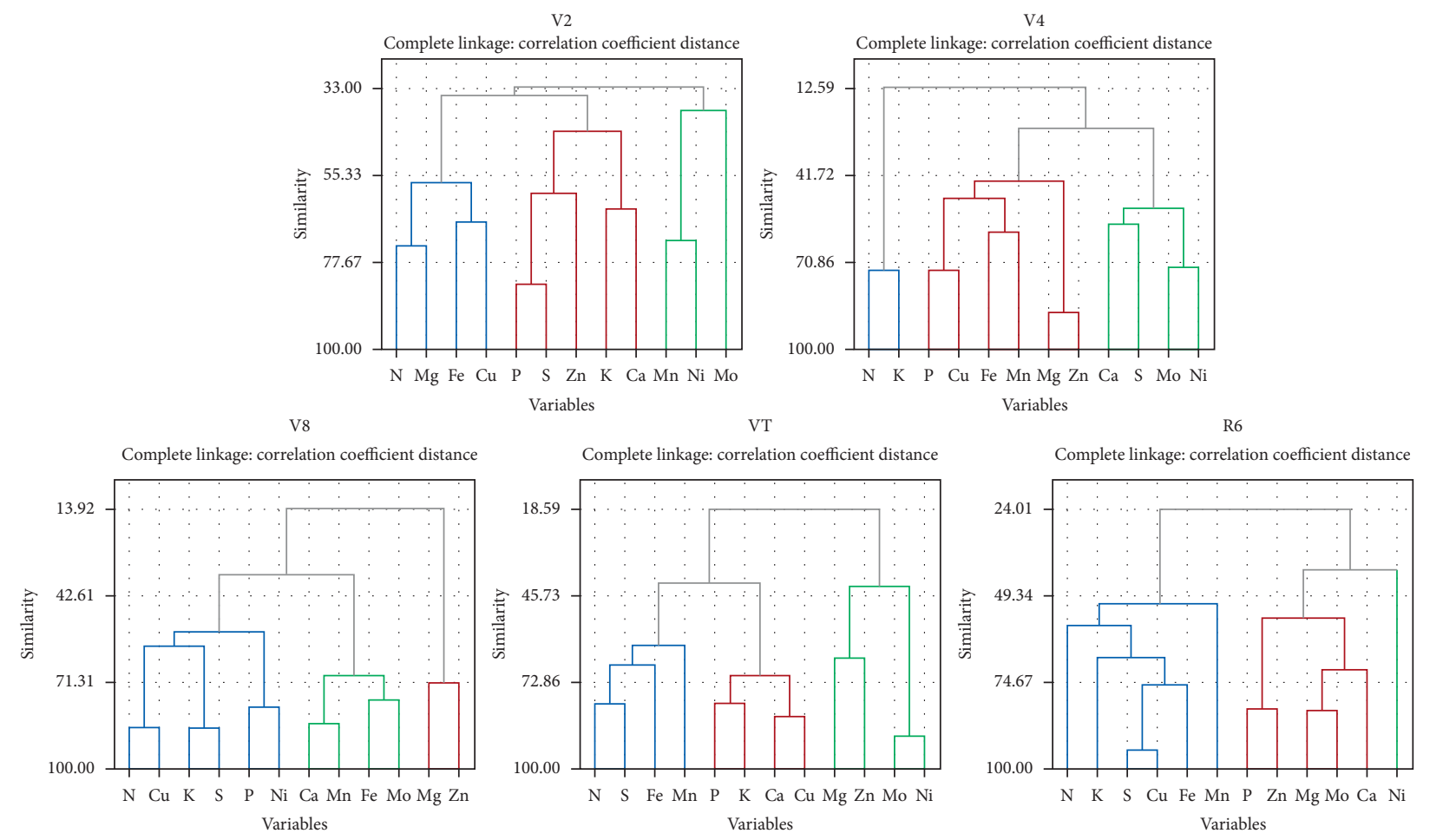

FIgUre 2: Cluster of sampling times in nutrients with means of NPK on leaves. Nitrogen $(\mathrm{N})$, potassium (K), phosphorus (P), magnesium $(\mathrm{Mg})$, calcium $(\mathrm{Ca})$, sulphur $(\mathrm{S})$, zinc $(\mathrm{Zn})$, iron $(\mathrm{Fe})$, copper $(\mathrm{Cu})$, manganese $(\mathrm{Mn})$, nickel $(\mathrm{Ni})$, and molybdenum $(\mathrm{Mo})$.
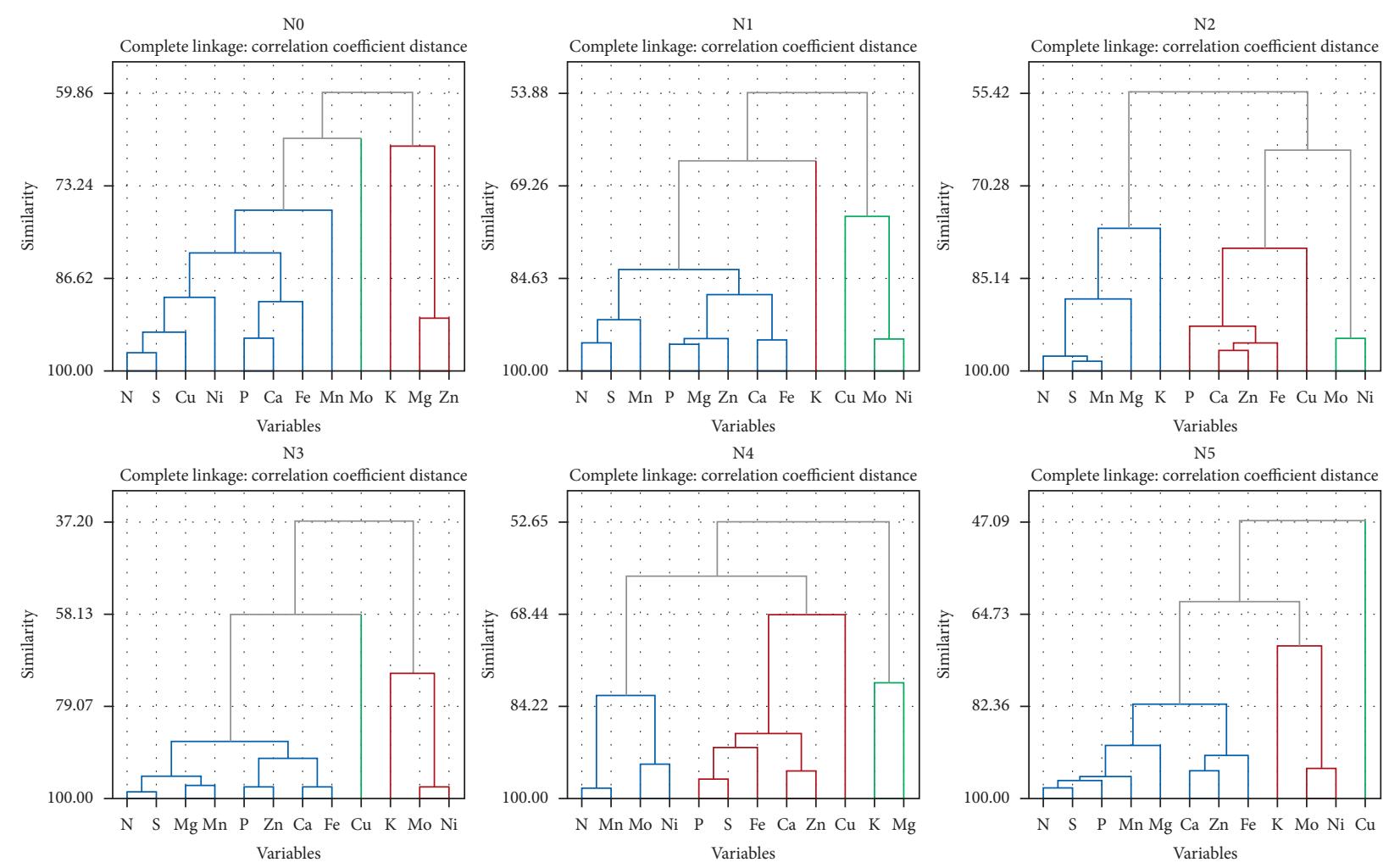

FIGURE 3: Cluster of NPK in nutrients with means of sampling times on stalk. Nitrogen (N), potassium (K), phosphorus (P), magnesium $(\mathrm{Mg})$, calcium $(\mathrm{Ca})$, sulphur $(\mathrm{S})$, zinc $(\mathrm{Zn})$, iron $(\mathrm{Fe})$, copper $(\mathrm{Cu})$, manganese $(\mathrm{Mn})$, nickel $(\mathrm{Ni})$, and molybdenum $(\mathrm{Mo})$. 

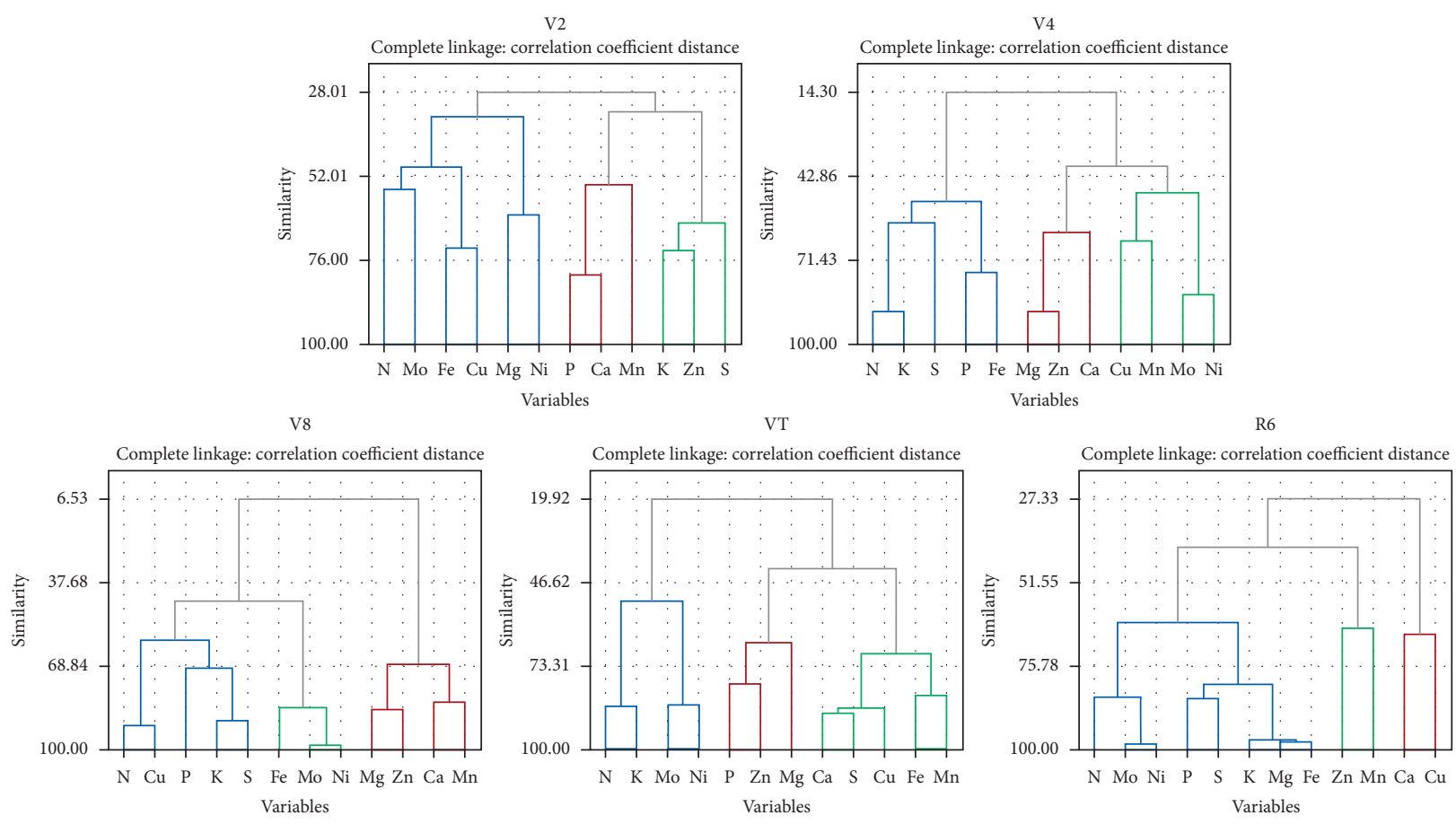

FIGURE 4: Cluster of sampling times in nutrients with means of NPK on stalk. Nitrogen (N), potassium (K), phosphorus (P), magnesium $(\mathrm{Mg})$, calcium $(\mathrm{Ca})$, sulphur $(\mathrm{S})$, zinc $(\mathrm{Zn})$, iron $(\mathrm{Fe})$, copper $(\mathrm{Cu})$, manganese $(\mathrm{Mn})$, nickel $(\mathrm{Ni})$, and molybdenum $(\mathrm{Mo})$. AMMI analysis of stalk and leaves.

molybdenum, iron with molybdenum and nickel, and molybdenum with nickel in the cobs. Phosphorus significantly correlated with potassium, magnesium, zinc, and iron, potassium with magnesium, and magnesium with zinc and iron in grains (Table 3 ).

3.2. Nutrient Composition of Leaves. The cluster analysis showed that the first cluster includes nitrogen, potassium, manganese, phosphorus, sulphur, iron, and molybdenum, while the second cluster includes nickel, and the third cluster includes magnesium, calcium, zinc, and copper in the control treatment (N0). Cluster analysis on the second treatment (N1) showed that the first cluster includes nitrogen, phosphorus, zinc, iron, manganese, potassium, and sulphur, while the second cluster includes magnesium, calcium, and copper, and the third cluster includes molybdenum and nickel. The first cluster includes nitrogen, phosphorus, zinc, iron, potassium, sulphur, and manganese, the second cluster includes molybdenum and nickel, and the third cluster includes manganese, calcium, and copper in the third treatment (N2). The fourth treatment (N3) first cluster includes nitrogen, sulphur, phosphorus, zinc, iron, potassium, magnesium, and calcium, the second cluster includes manganese, molybdenum, and nickel, and the third cluster includes copper. Cluster analysis on the fifth treatment (N4) showed that the first cluster includes nitrogen, potassium, phosphorus, zinc, iron, sulphur, manganese, and nickel, the second cluster includes molybdenum, and the third cluster includes magnesium, calcium, and copper. In the sixth treatment (N5), the first cluster includes nitrogen, potassium, sulphur, phosphorus, zinc, iron, manganese, molybdenum, and nickel, the second cluster includes magnesium and calcium, and the third cluster includes copper on the leaves parameter (Figure 1). Cluster analysis showed that the first cluster includes nitrogen, magnesium, iron, and copper, the second cluster includes phosphorus, sulphur, zinc, potassium, and calcium, and the third cluster includes manganese, nickel, and molybdenum in the V2 stage (V2). Cluster analysis on the V4 stage (V4) showed that the first cluster includes nitrogen and potassium, and the second cluster includes phosphorus, copper, iron, manganese, magnesium, and zinc, while the third cluster includes calcium, sulphur, molybdenum, and nickel. The first cluster includes nitrogen, copper, potassium, sulphur, phosphorus, and nickel, while the second cluster includes calcium, manganese, iron, and molybdenum, and the third cluster includes magnesium and zinc in the V8 stage (V8). The VT stage (VT) first cluster includes nitrogen, sulphur, iron, and manganese, the second cluster includes phosphorus, potassium, calcium, and copper, and the third cluster includes magnesium, zinc, molybdenum, and nickel. Cluster analysis on the R6 stage (R6) showed that the first cluster includes nitrogen, potassium, sulphur, copper, iron, and manganese, the second cluster includes phosphorus, zinc, magnesium, manganese, and calcium, and the third cluster includes nickel on the leaves parameter (Figure 2).

3.3. Nutrient Composition of Stalk. The cluster analysis showed that the first cluster includes nitrogen, sulphur, copper, nickel, phosphorus, calcium, iron, and manganese, the second cluster includes molybdenum, and the third cluster includes potassium, magnesium, and zinc in the control treatment (N0). Cluster analysis on the second 
TABLE 4: AMMI variance analysis on leaves and stalk.

\begin{tabular}{|c|c|c|c|c|c|c|}
\hline & Source & Degrees of freedom & Sum of squares & Mean of squares & F value & Variance explained \\
\hline \multirow{10}{*}{ Nutrients in NPK on leaves } & Total & 1559 & 224897 & 144.3 & $*$ & \\
\hline & Treatments & 77 & 10046 & 130.5 & 0.89 & \\
\hline & NPK & 5 & 613 & 122.6 & 0.84 & \\
\hline & Nutrients & 12 & 867 & 72.2 & 0.65 & \\
\hline & Block & 39 & 4333 & 111.1 & 0.76 & \\
\hline & Interactions & 60 & 8567 & 142.8 & 0.98 & \\
\hline & IPCA1 & 16 & 4314 & 269.6 & $1.85^{*}$ & $50.35 \%$ \\
\hline & IPCA2 & 14 & 2892 & 206.5 & 1.42 & $33.76 \%$ \\
\hline & Residuals & 30 & 1361 & 45.4 & 0.31 & $15.89 \%$ \\
\hline & Error & 1443 & 210518 & 145.9 & $*$ & \\
\hline \multirow{10}{*}{ Nutrients in sampling on leaves } & Total & 1559 & 224897 & 144.3 & $*$ & \\
\hline & Treatments & 64 & 7754 & 121.2 & 0.83 & \\
\hline & Sampling times & 4 & 945 & 236.3 & 1.62 & \\
\hline & Nutrients & 12 & 867 & 72.2 & 0.65 & \\
\hline & Block & 39 & 4333 & 111.1 & 0.76 & \\
\hline & Interactions & 48 & 5942 & 123.8 & 0.85 & \\
\hline & IPCA1 & 15 & 2970 & 198.0 & $1.35^{*}$ & $49.98 \%$ \\
\hline & IPCA2 & 13 & 1897 & 145.9 & 1.00 & $31.92 \%$ \\
\hline & Residuals & 20 & 1076 & 53.8 & 0.37 & $18.10 \%$ \\
\hline & Error & 1456 & 212810 & 146.2 & $*$ & \\
\hline \multirow{10}{*}{ Nutrients in NPK on stalk } & Total & 1559 & 231325 & 148.4 & $*$ & \\
\hline & Treatments & 77 & 12519 & 162.6 & 1.09 & \\
\hline & NPK & 5 & 285 & 57.0 & 0.38 & \\
\hline & Nutrients & 12 & 2330 & 194.2 & $1.79^{*}$ & \\
\hline & Block & 39 & 4232 & 108.5 & 0.73 & \\
\hline & Interactions & 60 & 9904 & 165.1 & 1.11 & \\
\hline & IPCA1 & 16 & 4807 & 300.5 & $2.02^{* *}$ & $48.54 \%$ \\
\hline & IPCA2 & 14 & 3657 & 261.2 & 1.76 & $36.93 \%$ \\
\hline & Residuals & 30 & 1439 & 48.0 & 0.32 & $14.53 \%$ \\
\hline & Error & 1443 & 214574 & 148.7 & $*$ & \\
\hline \multirow{10}{*}{ Nutrients in sampling on stalk } & Total & 1559 & 231325 & 148.4 & $*$ & \\
\hline & Treatments & 64 & 10418 & 162.8 & 1.09 & \\
\hline & Sampling times & 4 & 383 & 95.8 & 0.64 & \\
\hline & Nutrients & 12 & 2330 & 194.2 & $1.79^{*}$ & \\
\hline & Block & 39 & 4232 & 108.5 & 0.73 & \\
\hline & Interactions & 48 & 7704 & 160.5 & 1.08 & \\
\hline & IPCA1 & 15 & 5252 & 350.1 & $2.35^{* *}$ & $68.17 \%$ \\
\hline & IPCA2 & 13 & 1601 & 123.2 & 0.83 & $20.78 \%$ \\
\hline & Residuals & 20 & 851 & 42.6 & 0.29 & $11.05 \%$ \\
\hline & Error & 1456 & 216675 & 148.8 & * & \\
\hline
\end{tabular}

treatment (N1) showed that the first cluster includes nitrogen, sulphur, manganese, phosphorus, magnesium, zinc, calcium, and iron, the second cluster includes potassium, and the third cluster includes copper, molybdenum, and nickel. The first cluster includes nitrogen, sulphur, manganese, magnesium, and potassium, the second cluster includes phosphorus, calcium, zinc, iron, and calcium, and the third cluster includes molybdenum and nickel in the third treatment (N2). The fourth treatment (N3) first cluster includes nitrogen, sulphur, magnesium, manganese, phosphorus, zinc, calcium, and iron, the second cluster includes copper, and the third cluster includes potassium, molybdenum, and nickel. Cluster analysis on the fifth treatment (N4) showed that the first cluster includes nitrogen, manganese, molybdenum, and nickel, the second cluster includes phosphorus, sulphur, iron, calcium, zinc, and copper, and the third cluster includes potassium and magnesium. In the sixth treatment (N5), the first cluster includes nitrogen, sulphur, phosphorus, manganese, magnesium, calcium, zinc, and iron, the second cluster includes potassium, molybdenum, and nickel, and the third cluster includes copper on stalk parameter (Figure 3). Cluster analysis showed that the first cluster includes nitrogen, molybdenum, iron, copper, magnesium, and nickel, the second cluster includes phosphorus and calcium, and the third cluster includes potassium, zinc, and sulphur in the V2 stage (V2). Cluster analysis on the V4 stage (V4) showed that the first cluster includes nitrogen, potassium, sulphur, and iron, the second cluster includes magnesium, zinc, and calcium, and the third cluster includes copper, manganese, molybdenum, and nickel. The first cluster includes nitrogen, copper, phosphorus, potassium, and sulphur, the second cluster includes iron, molybdenum, and nickel, and the third cluster includes magnesium, zinc, calcium, and manganese in the V8 stage (V8). The VT stage (VT) first cluster includes nitrogen, potassium, molybdenum, and nickel, the second 


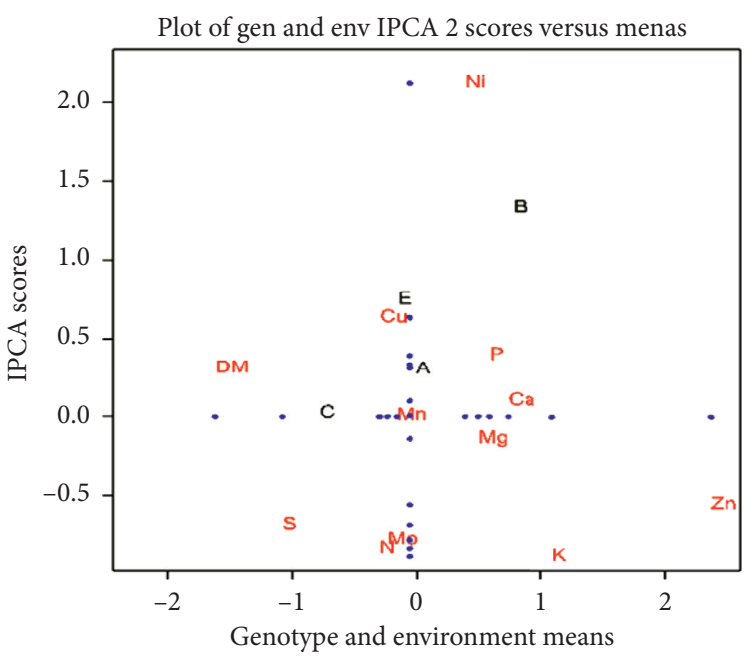

(a)

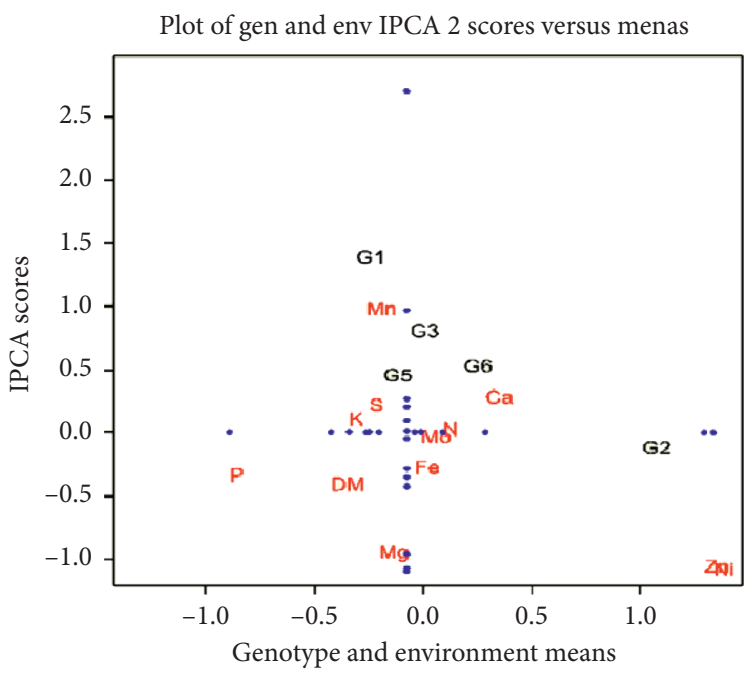

(c)

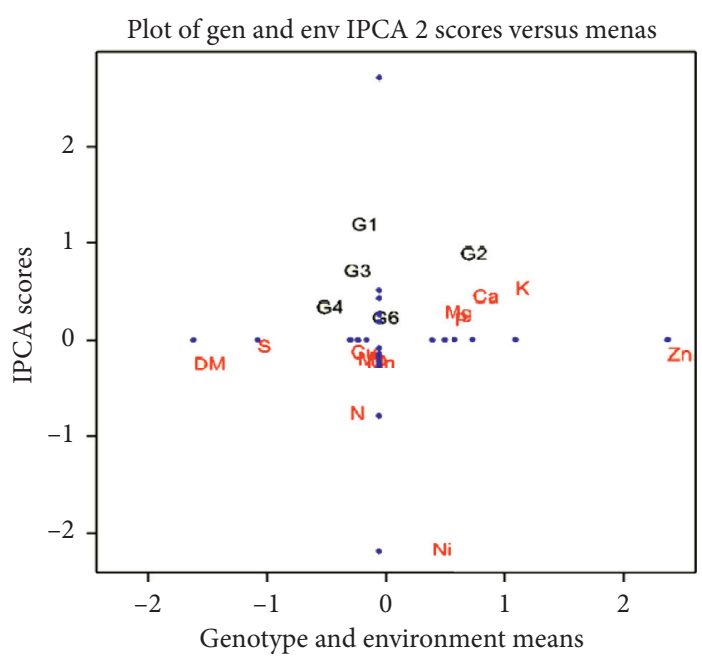

(b)

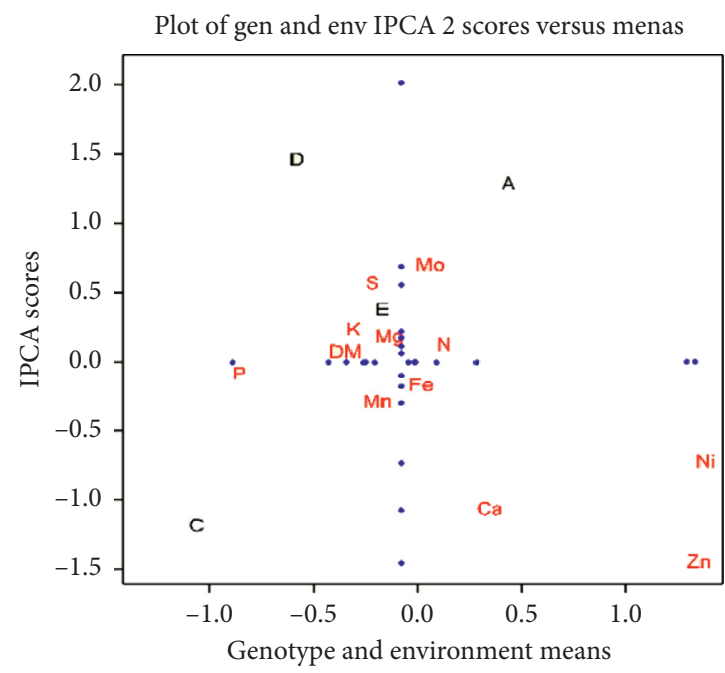

(d)

FIgURe 5: AMMI Biplot on leaves and stalk. (a) AMMI Biplot interaction sampling times in nutrient on stalk, (b) AMMI Biplot interaction NPK in nutrient on stalk, (c) AMMI Biplot interaction sampling times in nutrient on leaves, (d) AMMI Biplot interaction NPK in nutrient on leaves. G1-G6 (treatments N0 -N5), A-E (sampling times). Nitrogen (N), potassium (K), phosphorus (P), magnesium (Mg), calcium $(\mathrm{Ca})$, sulphur $(\mathrm{S})$, zinc $(\mathrm{Zn})$, iron $(\mathrm{Fe})$, copper $(\mathrm{Cu})$, manganese $(\mathrm{Mn})$, nickel $(\mathrm{Ni})$, and molybdenum $(\mathrm{Mo})$. Nutrient composition of grain and cob.

cluster includes phosphorus, zinc, and magnesium, and the third cluster includes calcium, sulphur, copper, iron, and manganese. Cluster analysis on the R6 stage (R6) showed that the first cluster includes nitrogen, molybdenum, nickel, phosphorus, sulphur, potassium, magnesium, and iron, the second cluster includes zinc and manganese, and the third cluster includes calcium and copper on stalk parameter (Figure 4).

The AMMI analysis showed significant interaction of the principal component analysis on nutrient in NPK on leaves with $50.35 \%$ of total data, on nutrient in sampling times on leaves with $49.98 \%$ of total data, on nutrient in NPK on stalk with $48.54 \%$ of total data, and on nutrient in sampling times on stalk with $68.17 \%$ of total data. The impact of nutrients was significant on the interaction of nutrient in NPK and nutrient in sampling times in the stalk (Table 4). AMMI biplot showed that sampling time V2 and R6 with manganese, copper, and phosphorus have favourable stability or maximum effect of yield on interaction sampling times nutrient on the stalk. In addition, R6 with nitrogen, iron, magnesium, and manganese has sustainability on interaction sampling times nutrient on leaves stage. Maximum effect or sustainability exists in N5, N4, and N2 with copper, magnesium, and manganese on interaction NPK in nutrients on the stalk. Also, N4 with nitrogen, molybdenum, sulphur, potassium, and iron had maximum effect on performance and favourable stability on interaction NPK in nutrients in the leaves stage (Figure 5).

Cluster analysis showed that the first cluster includes nitrogen and copper, the second cluster includes phosphorus, magnesium, and manganese, and the third cluster includes potassium, molybdenum, calcium, zinc, sulphur, 

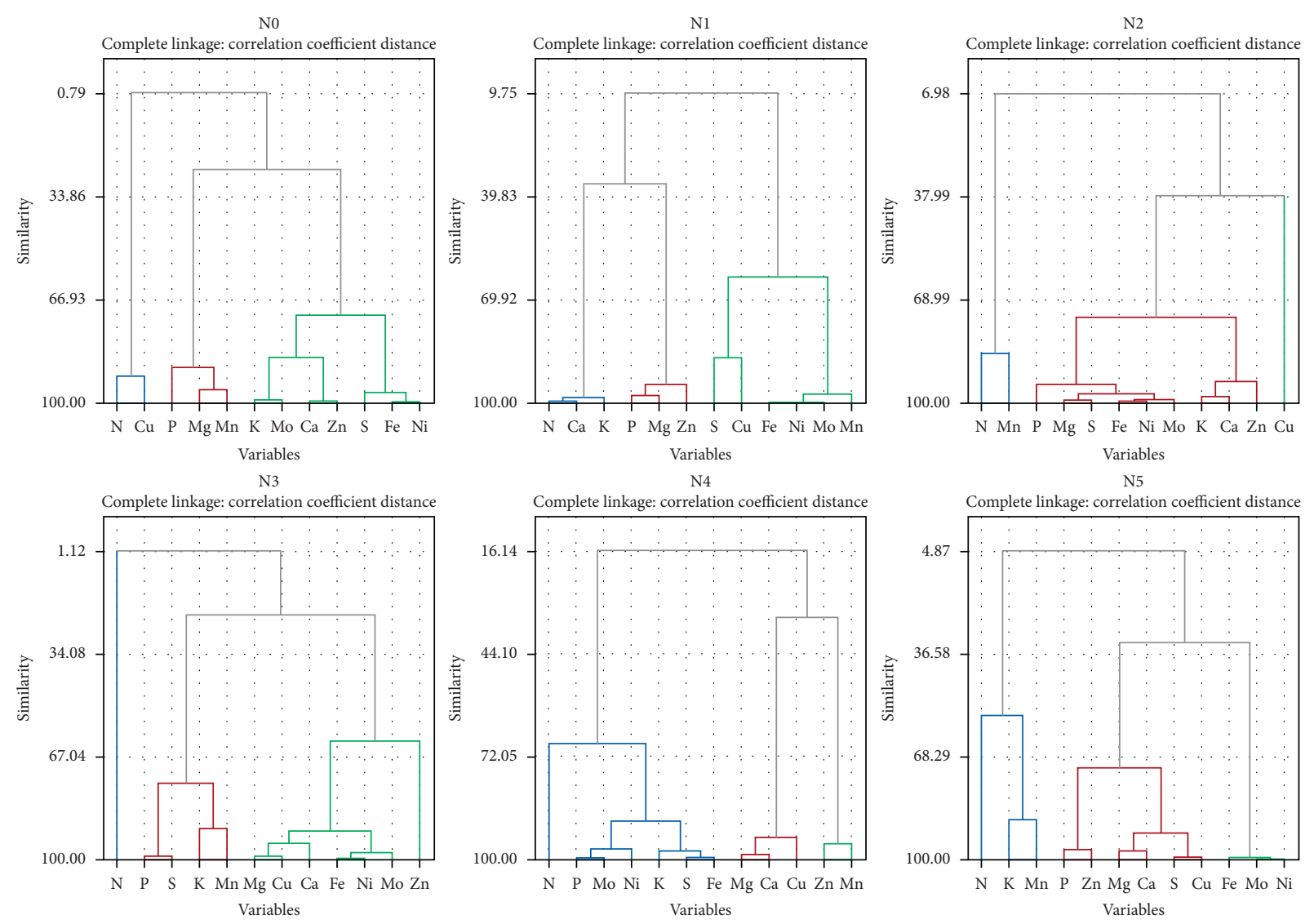

Figure 6: Cluster of NPK in nutrients of cob. Nitrogen $(\mathrm{N})$, potassium $(\mathrm{K})$, phosphorus $(\mathrm{P})$, magnesium $(\mathrm{Mg})$, calcium $(\mathrm{Ca})$, sulphur $(\mathrm{S})$, zinc $(\mathrm{Zn})$, iron $(\mathrm{Fe})$, copper $(\mathrm{Cu})$, manganese $(\mathrm{Mn})$, nickel $(\mathrm{Ni})$, and molybdenum $(\mathrm{Mo})$.

iron, and nickel in the control treatment (N0). Cluster analysis on the second treatment (N1) showed that the first cluster includes nitrogen, calcium, and potassium, the second cluster includes phosphorus, magnesium, and zinc, and the third cluster includes sulphur, copper, iron, nickel, molybdenum, and manganese. The first cluster includes nitrogen and manganese, the second cluster includes phosphorus, magnesium, sulphur, iron, nickel, molybdenum, potassium, calcium, and zinc, and the third cluster includes copper in the third treatment (N2). The fourth treatment (N3) first cluster includes nitrogen, the second cluster includes phosphorus, sulphur, potassium, and manganese, and the third cluster includes magnesium, copper, calcium, iron, nickel, molybdenum, and zinc. Cluster analysis on the fifth treatment (N4) showed that the first cluster includes nitrogen, phosphorus, molybdenum, nickel, potassium, sulphur, and iron, the second cluster includes magnesium, calcium, and copper, and the third cluster includes zinc and manganese. In the sixth treatment (N5), the first cluster includes nitrogen, potassium, and manganese, the second cluster includes phosphorus, zinc, magnesium, calcium, sulphur, and copper, and the third cluster includes iron, molybdenum, and nickel on cob parameter (Figure 6). Cluster analysis showed that the first cluster includes nitrogen, calcium, molybdenum, and sulphur, the second cluster includes phosphorus, magnesium, potassium, zinc, manganese, and iron, and the third cluster includes copper and nickel in the control treatment (N0). Cluster analysis on the second treatment (N1) showed that the first cluster includes nitrogen, potassium, copper, calcium, phosphorus, zinc, and magnesium, the second cluster includes sulphur, molybdenum, and iron, and the third cluster includes manganese and nickel. The first cluster includes nitrogen, nickel, and copper, the second cluster includes phosphorus, calcium, manganese, magnesium, molybdenum, potassium, and iron, and the third cluster includes sulphur and zinc in the third treatment (N2). The fourth treatment (N3) first cluster includes nitrogen and calcium, the second cluster includes phosphorus, magnesium, potassium, iron, and molybdenum, and the third cluster includes sulphur, zinc, nickel, copper, and manganese. Cluster analysis on the fifth treatment (N4) showed that the first cluster includes nitrogen, zinc, phosphorus, manganese, magnesium, potassium, and $\mathrm{Ni}$, the second cluster includes sulphur and molybdenum, and the third cluster includes calcium, iron, and copper. In the sixth treatment (N5), the first cluster includes nitrogen, copper, molybdenum, calcium, and nickel, the second cluster includes iron and manganese, and the third cluster includes phosphorus, magnesium, potassium, sulphur, and zinc on the grain parameters (Figure 7). 

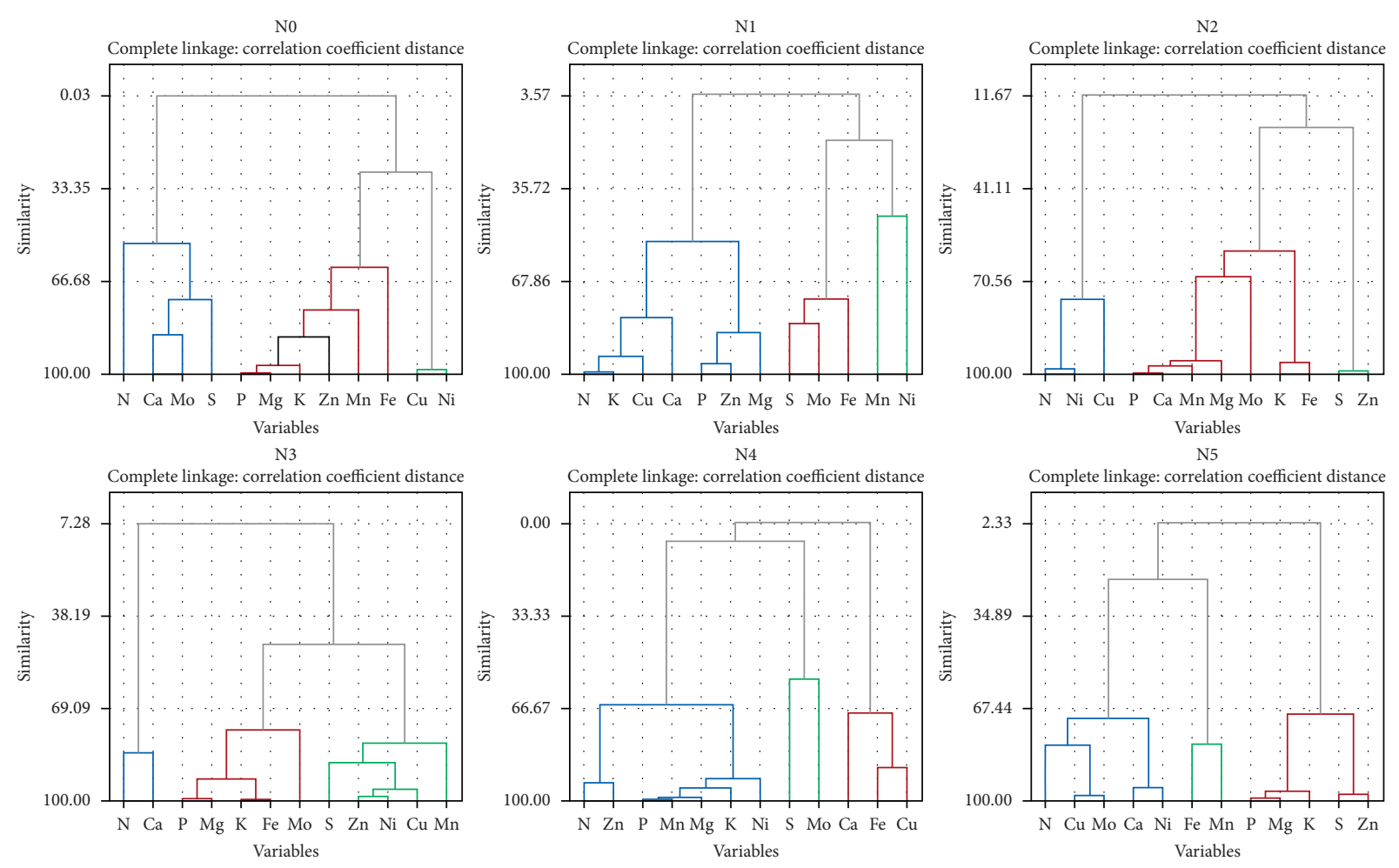

Figure 7: Cluster of NPK in nutrients of grain. Nitrogen $(\mathrm{N})$, potassium $(\mathrm{K})$, phosphorus $(\mathrm{P})$, magnesium $(\mathrm{Mg})$, calcium $(\mathrm{Ca})$, sulphur (S), zinc $(\mathrm{Zn})$, iron $(\mathrm{Fe})$, copper $(\mathrm{Cu})$, manganese $(\mathrm{Mn})$, nickel $(\mathrm{Ni})$, and molybdenum $(\mathrm{Mo})$.

\section{Discussion}

Total nitrogen was an essential factor of maize in all growth stages. Increased nitrogen fertiliser leads to more dry matter production and grain yield. Also, increasing nitrogen accelerates green growth, increases the above-ground mass of the plant, and increases the evaporation of plants and causes the roots to expand and bulk up [18]. Numerous reports recorded the positive effect of nitrogen on grain growth per grain, grain weight, and grain yield of maize, with a tendency to use higher amounts of nitrogen fertiliser [19-21].

This study shows that essential nutrients include nitrogen, phosphorus, potassium, sulphur (in first cluster) and calcium and magnesium (in second cluster) in the different leaf stages. The growth stages of maize have different nutrient demands. Phosphorus and nitrogen should be provided to the plant immediately after germination to start growing stems, leaves, and shoots. Insufficient nitrogen supply after one or two weeks of planting to the sixth week reduces the plant's potential yield [22-24]. Current results indicate that sulphur, potassium, molybdenum, and nitrogen had maximum effect on NPK treatments, and molybdenum, potassium, and iron had maximum effect on growth stage on leaves. The highest uptake of phosphorus occurs in the sowing stage, but phosphorus uptake in the whole plant decreases in the ripening stage [23, 25].

Iron is a useful element in photosynthesis and has a special role in plant nutrition. However, the high percentage of bicarbonate and carbonate in the soil causes iron deficiency in plants [26]. Some research studies indicate the effect of iron and manganese fertilisers on quantitative and qualitative traits and the positive role of these elements in increasing maize protein. Also, the lack of these elements has a negative effect on the percentage of protein and other quality characteristics of corn [27-31].

The first cluster includes nitrogen and sulphur and the second includes calcium and zinc in the NPK treatments on stalk. Nitrogen and potassium had their maximum effect on the stalk during the vegetative growth period. Manganese and copper were important and favourable for the different growth stages and treatments on the stalk. Adding iron and manganese fertiliser is recommended if the amount of these elements is less than optimal, causing discoloration other than chlorophyll in leaves and the reduction of growth regulator factors in the plant. This study indicated that increasing nitrogen negatively correlates with zinc and cooper; that is, increasing amount of nitrogen causes decreasing zinc and copper. Also, an increasing amount of potassium caused decreasing iron and manganese concentration. Phosphorous correlated negatively with nickel and copper. The iron and manganese fertiliser use increases photosynthesis and transfers photosynthetic materials to different parts of the plant, thereby growing the stem. Improving nutritional conditions and the positive role of iron can be useful in photosynthesis and optical photosystems' performance in increasing growth indices such as stem diameter [32-34]. Nitrogen and calcium had a maximum impact for grain stage and nitrogen and phosphorus had a favourable effect during the cob-corn stage. The nitrogen effect on the quantitative and qualitative properties of maize 
showed that nitrogen increases the production of dry matter, grain yield, and its components. If there is adequate nitrogen in the soil, crops will have vegetative growth, larger leaf area, and significant yield [29, 35-44].

\section{Conclusion}

Identifying different stages of plant growth and determining its absorption pattern according to growth stages is one of the best ways to properly manage input consumption, which is essential in achieving proper management and determining the amount and time of consumption that helps to prevent the effects of deficiency. The maximum amount of absorption in the plant occurs before the accumulation of maximum nutrients, which is the prelude to the production of maximum biomass of the plant. Therefore, the use of fertiliser before the maximum stage of plant needs is essential and vital, which leads to reducing the risk of nutrient deficiencies and preventing a reduction in crop yield. This type of management reduces fertiliser waste, increases nutrient efficiency, and is an environmentally sensitive strategy. Using soil test and plant nutrient uptake curves will help farmers achieve the desired amount and time of inputs. It should be noted that more accurate inputs based on plant needs at different stages of growth require long-term research in each region.

\section{Data Availability}

All data supporting the conclusions of this article are included in this article.

\section{Consent}

Consent by the authors was provided to publish their results.

\section{Conflicts of Interest}

The authors declare that they have no conflicts of interest.

\section{Authors' Contributions}

$\mathrm{CB}$ carried out the experiment and wrote the manuscript. LCM initiated and suggested the experiments and is responsible for this study. AI completed the plant sampling in the field. BT performed the laboratory measurements. SMNM carried out the statistical analysis and reviewed the manuscript. AS created the figures and reviewed the manuscript. JN reviewed and finalized the manuscript. All authors read and approved the final manuscript.

\section{Acknowledgments}

Project no. TKP2020-IKA-04 has been implemented with the support provided from the National Research, Development and Innovation Fund of Hungary, financed under the 2020-4.1.1-TKP2020 funding scheme and supported by the EFOP-3.6.3-VEKOP-16-2017-00008 Project.

\section{References}

[1] X. Xin, J. Zhang, A. Zhu, and C. Zhang, "Effects of longterm (23 years) mineral fertilizer and compost application on physical properties of fluvo-aquic soil in the North China Plain," Soil and Tillage Research, vol. 156, pp. 166-172, 2016.

[2] R. R. Bender, J. W. Haegele, M. L. Ruffo, and F. E. Below, "Nutrient uptake, partitioning, and remobilization in modern, transgenic insect-protected maize hybrids," Agronomy Journal, vol. 105, no. 1, pp. 161-170, 2013.

[3] R. K. Pandey, J. W. Maranville, and A. Admou, "Deficit irrigation and nitrogen effects on maize in a Sahelian environment," Agricultural Water Management, vol. 46, no. 1, pp. 1-13, 2000.

[4] W. R. Raun and G. V. Johnson, "Improving nitrogen use efficiency for cereal production," Agronomy Journal, vol. 91, no. 3, pp. 357-363, 1999.

[5] U. Surendran, V. Murugappan, A. Bhaskaran, and R. Jagadeeswaran, "Nutrient budgeting using NUTMONToolbox in an irrigated farm of semi arid tropical region in India-A micro and meso level modeling study," World Journal of Agricultural Sciences, vol. 1, no. 1, pp. 89-97, 2005.

[6] L. J. Abendroth, R. W. Elmore, M. J. Boyer, and S. K. Marlay, Understanding Corn Development: A Key for Successful Crop Management, Nova Publisher, Hauppauge, NY, USA, 2010.

[7] P. Kovács and T. J. Vyn, "Relationships between ear-leaf nutrient concentrations at silking and corn biomass and grain yields at maturity," Agronomy Journal, vol. 109, no. 6, pp. 2898-2906, 2017.

[8] P. C. Scharf, W. J. Wiebold, and J. A. Lory, "Corn yield response to nitrogen fertilizer timing and deficiency level," Agronomy Journal, vol. 94, no. 3, pp. 435-441, 2002.

[9] I. A. Ciampitti, J. J. Camberato, S. T. Murrell, and T. J. Vyn, "Maize nutrient accumulation and partitioning in response to plant density and nitrogen rate: I. Macronutrients," Agronomy Journal, vol. 105, no. 3, pp. 783-795, 2013.

[10] G. Mi, J. A. Liu, F. Chen, F. Zhang, Z. Cui, and X. Liu, "Nitrogen uptake and remobilization in maize hybrids differing in leaf senescence," Journal of Plant Nutrition, vol. 26, no. 1, pp. 237-247, 2003.

[11] H. Marschner, Marschner's Mineral Nutrition of Higher Plants, Academic Press, Cambridge, MA, USA, 2011.

[12] C. Curie, G. Cassin, D. Couch et al., "Metal movement within the plant: contribution of nicotianamine and yellow stripe 1like transporters," Annals of Botany, vol. 103, no. 1, pp. 1-11, 2009.

[13] Q. Chen, X. Mu, F. Chen, L. Yuan, and G. Mi, "Dynamic change of mineral nutrient content in different plant organs during the grain filling stage in maize grown under contrasting nitrogen supply," European Journal of Agronomy, vol. 80, pp. 137-153, 2016.

[14] I. A. Ciampitti and T. J. Vyn, "Nutrient sufficiency concepts for modern corn hybrids: impacts of management practices and yield levels," Crop Management, vol. 13, no. 1, pp. 1-7, 2014.

[15] J. Nagy, "Complex long-term experiments on soil use, water and nutrient management at the University of Debrecen since 1983," Növénytermelés, vol. 68, no. 3, pp. 5-28, 2019.

[16] T. B. Tarantino, I. S. Barbosa, D. de C. Lima, M. De G. Pereira, L. S. G. Teixeira, and M. G. A. Korn, "Microwave-assisted digestion using diluted nitric acid for multi-element determination in rice by ICP OES and ICP-MS," Food Analytical Methods, vol. 10, no. 4, pp. 1007-1015, 2017. 
[17] M. E. Ebeling, "The Dumas method for nitrogen in feeds," Journal of Aoac International, vol. 51, no. 4, pp. 766-770, 1968.

[18] Z. I. Ali, S. E. Dawelbeit, and A. A. Salih, Effect of Water Stress and Nitrogen Application on Grain Yield of Wheat, Agricultural Research and Technology Corporation Unit, New Delhi, India, 2006.

[19] A. Asghar, W. Muhammad, T. Asif, T. Muhammad, M. A. Nadeem, and M. S. I. Zamir, "Impact of nitrogen application on growth and yield of maize (Zea mays L.) grown alone and in combination with cowpea (Vigna unguiculata L.)," American-eurasian Journal of Agricultural and Environmental Science, vol. 7, no. 1, pp. 43-47, 2010.

[20] R. S. Sharifi and R. Taghizadeh, "Response of maize (Zea mays L.) cultivars to different levels of nitrogen fertilizer," Journal of Food, Agriculture \& Environment, vol. 7, no. 3/4, pp. 518-521, 2009.

[21] A. Illes, C. Bojtor, A. Szeles, S. M. N. Mousavi, B. Toth, and J. Nagy, "Analyzing the effect of intensive and low-input agrotechnical support for the physiological, phenometric, and yield parameters of different maize hybrids using multivariate statistical methods," International Journal of Agronomy, vol. 2021, 2021.

[22] C. Jones, Grasses and Cereals: Growth, Development and Stress Response, John Wiley \& Sons, New York, NY, USA, 1985.

[23] K. Girma, K. L. Martin, K. W. Freeman et al., "Determination of optimum rate and growth stage for foliar-applied phosphorus in corn," Communications in Soil Science and Plant Analysis, vol. 38, no. 9-10, pp. 1137-1154, 2007.

[24] M. A. Licht and M. Al-Kaisi, "Corn response, nitrogen uptake, and water use in strip-tillage compared with No-tillage and chisel plow," Agronomy Journal, vol. 97, no. 3, pp. 705-710, 2005.

[25] R. B. Austin, M. A. Ford, J. A. Edrich, and R. D. Blackwell, "The nitrogen economy of winter wheat," The Journal of Agricultural Science, vol. 88, no. 1, pp. 159-167, 1977.

[26] M. Sipos, "The effect of hybrid, nutrient-supply and irrigation on the grain moisture content at harvest and the starchcontent of maize (Zea mays L.)," Acta Agraria Debreceniensis, vol. 35, pp. 89-95, 2009.

[27] Y. Xue, S. Yue, W. Zhang et al., "Zinc, iron, manganese and copper uptake requirement in response to nitrogen supply and the increased grain yield of summer maize," PloS One, vol. 9, no. 4, Article ID e93895, 2014.

[28] M. Wyszkowski and M. S. Brodowska, "Potassium and nitrogen fertilization vs. Trace element content of maize (Zea mays L.)," Agriculture, vol. 11, no. 2, p. 96, 2021.

[29] F. Montemurro and D. De Giorgio, "Quality and nitrogen use efficiency of sunflower grown at different nitrogen levels under Mediterranean conditions," Journal of Plant Nutrition, vol. 28, no. 2, pp. 335-350, 2005.

[30] J. J. Mortvedt, "Research techniques with micronutrient fertilizers for use in efficient crop production," in International Symposium on the Role of Sulphur, Magnesium and Micronutrients in Balanced Plant Nutrition/sponsors, the Potash and Phosphate Institute of Canada, S. Portch, Ed., Potash and Phosphate Institute, Hong Kong, China, 1991.

[31] E. N.., ,. Whitty and C. G. Chambliss, Fertilization of Field and Forage Crops Nevada State, pp. 21-22, Elsevier, Amsterdam, Netherlands, 2005.

[32] A. M. Massignam, S. C. Chapman, G. L. Hammer, and S. Fukai, "Physiological determinants of maize and sunflower grain yield as affected by nitrogen supply," Field Crops Research, vol. 113, no. 3, pp. 256-267, 2009.
[33] M. J. Malakoti and M. M. Tehrani, "Effects of micronutrients on the yield and quality of agricultural products," Tarbiat Modarres University Publications, vol. 22, pp. 292-294, 1999.

[34] A. Baybordi, "Effect of Fe, Mn, Zn and Fe on the quality and quantity under salinity stress," Water and Soil Science, vol. 17, no. 3, pp. 145-149, 2001.

[35] T. Presterl, S. Groh, M. Landbeck, G. Seitz, W. Schmidt, and H. H. Geiger, "Nitrogen uptake and utilization efficiency of European maize hybrids developed under conditions of low and high nitrogen input," Plant Breeding, vol. 121, no. 6, pp. 480-486, 2002.

[36] F. Chen, Z. Fang, Q. Gao et al., "Evaluation of the yield and nitrogen use efficiency of the dominant maize hybrids grown in North and Northeast China," Science China Life Sciences, vol. 56, no. 6, pp. 552-560, 2013.

[37] S. M. N. Mousavi and J. Nagy, "Evaluation of plant characteristics related to grain yield of FAO410 and FAO340 hybrids using regression models," Cereal Research Communications, vol. 49, no. 1, pp. 161-169, 2021.

[38] S. M. N. Mousavi, K. Kith, and J. Nagy, "Effect of interaction between traits of different genotype maize in six fertilizer level by GGE biplot analysis in Hungary," Progress in Agricultural Engineering Sciences, vol. 15, no. 1, pp. 23-35, 2019.

[39] Á. Illés, S. M. N. Mousavi, C. Bojtor, and J. Nagy, "The plant nutrition impact on the quality and quantity parameters of maize hybrids grain yield based on different statistical methods," Cereal Research Communications, vol. 48, no. 4, pp. 565-573, 2020.

[40] E. M. Hafez and K. A. Abdelaal, "Impact of nitrogen fertilization levels on morphophysiological characters and yield quality of some maize hybrids (Zea mays L.). Egypt," Agronomy Journal, vol. 37, no. 1, pp. 35-48, 2015.

[41] E. E. E. Kandil, "Response of some maize hybrids (Zea mays L.) to different levels of nitrogenous fertilization," Journal of Applied Sciences Research, vol. 9, no. 3, pp. 1902-1908, 2013.

[42] V. Rajičić, V. Popović, V. Perišić et al., "Impact of nitrogen and phosphorus on grain yield in winter triticale grown on degraded Vertisol,” Agronomy, vol. 10, no. 6, p. 757, 2020.

[43] D. Božović, V. Popović, V. Rajicić et al., "Stability of the expression of the maize productivity parameters by AMMI models and GGE-biplot analysis," Notulae Botanicae Horti Agrobotanici Cluj-Napoca, vol. 48, no. 3, pp. 1387-1397, 2020.

[44] V. RajiČIĆ, V. PopoviĆ, D. TerziĆ et al., "Impact of lime and NPK fertilizers on yield and quality of oats on pseudogley soil and their valorisation," Notulae Botanicae Horti Agrobotanici Cluj-Napoca, vol. 48, no. 4, pp. 2134-2152, 2020. 